\title{
1 Application of Single-grain OSL dating to ice-proximal deposits, glacial Lake Benson, west-central 2 Minnesota, USA
}

3 Tammy M. Rittenour - Utah State University, Department of Geology, Logan Utah,

4 tammy.rittenour@usu.edu

5 James F.P. Cotter - University of Minnesota-Morris, Division of Math and Science, Morris Minnesota

6 Heather E. Arends - Minnesota Department of Natural Resources, St. Paul Minnesota

7

\section{ABSTRACT}

更

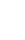

Glacial Lake Benson formed in west-central Minnesota as the Des Moines Lobe of the Laurentide ice sheet retreated north of a small moraine in the Minnesota River lowland. Although previous research has constrained the timing of Glacial Lake Agassiz immediately to the north, little age control is available for the formation of glacial Lake Benson and ice-marginal positions to the south. In order to constrain the age of glacial Lake Benson and test the application of single-grain optically stimulated luminescence (OSL) dating to ice-marginal deposits, seven OSL samples were collected from a variety of depositional settings. These included deltaic deposits linked to specific lake levels, pro-glacial fluvial, ice-contact and supra-glacial deposits. Single-grain OSL results indicate evidence for incomplete resetting (partial bleaching) of the luminescence signal, as expected for glacial environments, and therefore ages were calculated using a minimum age model. OSL results constrain the timing of ice-margin retreat and lake formation to $14.4-14.8 \mathrm{ka}$. Analysis of single-grain equivalent dose distributions indicates that deposits created by glacial-dominated processes typically had higher over-dispersion ( $>50 \%)$ and greater positive skew $(>0.9)$ than deposits originating from fluvial processes. These results suggest that water-lain deposits should be targeted for OSL sampling over those created by glacial processes when dating iceproximal settings. 


\section{Introduction}

Glacial volume and related ice positions reflect the climate-driven mass balance between ice accumulation and ablation. Therefore, reconstructed ice-margin positions record ice-sheet response to past climate change; a subject of interest in light of future projected sea-level rise due to melting of the

31 Greenland and west-Antarctic ice sheets (e.g. Overpeck et al. 2006). Moreover, reconstructions of ice-

32 retreat and drainage reorganization are important for understanding linkages between meltwater discharge and cooling events during deglaciation (e.g. Clark et al., 2001). However without good age control, relationships between glacial dynamics, meltwater discharge and climate change cannot be assessed. While ice-retreat chronologies exist for the southern margins of the Laurentide ice sheet (e.g. Dyke and Prest, 1987), the multi-centennial to millennial-scale resolution of these reconstructions are

37 difficult to reconcile with the annual to decadal-scale resolution of available climate records, such as

38 from the Greenland ice sheet (e.g. Steffensen et al., 2008).

Age control for ice-margin positions along the southern Laurentide ice sheet has been largely limited by the scarcity of material for radiocarbon dating in pro-glacial settings. Moreover, most radiocarbondated sequences only provide minimum age estimates for ice-retreat due to the delay in vegetative

42 succession in recently deglaciated landscapes (e.g. Cotter et al., 1984). Additional uncertainties arise 43 when radiocarbon ages are calibrated to allow comparison to other records, due to large variations in 44 atmospheric radiocarbon during deglaciation (e.g. Hughen et al., 2000; Reimer et al., 2013). These problems with radiocarbon-dated sequences have been side-stepped in unique cases where calibrated varve chronologies have been developed (e.g. Ridge et al. 2012), locations where ice re-advance has

47 over-run forest beds (e.g. the Two Creeks re-advance in Wisconsin, Black, 1976) and situations where 48 suitable boulders for cosmogenic dating are available (e.g. Balco et al., 2002). 
Optically stimulated luminescence (OSL) dating (Huntley et al., 1985) may provide an avenue to

50 better constrain ice-retreat chronologies, as quartz- and feldspar-rich sand for dating is abundant in

51 glacial settings. However, OSL dating requires sufficient exposure of sediment to sunlight prior to

52 deposition in order to reset the luminescence signal, which can be difficult to accomplish in glacial

53 settings where sediments are sourced from sub-glacial settings and high sediment loads are common

54 (e.g. Fuchs and Owen, 2008; Wyshnytzky et al., 2015). Technological advances in methods and

55 instrumentation have allowed for the development of single-aliquot (Murray and Wintle, 2000) and

56 single-grain (Duller et al. 1999) dating techniques that can be used to expand the applications of OSL

57 dating to more challenging environments (e.g. Rittenour 2008; Duller 2008; Rhodes, 2011). The purpose

58 of this paper is to test the application of single-grain OSL dating to ice-marginal deposits in a continental

59 ice sheet setting and to provide the first age control for ice retreat and formation of glacial Lake Benson

60 in west-central Minnesota, USA.

61

62

63

64

65

66

67

68

69

70

71

\section{Background}

Portions of Minnesota and lowa in north-central United States were glaciated by the Des Moines lobe, an ice stream fed by the Keewatin sector of the Laurentide ice sheet (Clayton and Moran, 1982). In the absence of a well constrained chronology it has been suggested that the late-glacial Des Moines lobe experienced multiple periods of rapid ice advance followed by regional stagnation (e.g. Patterson, 1997, 1998; Clayton and Moran, 1982; Jennings, 2006). These dynamic ice-lobe fluctuations are suggested to have been driven by episodic low basal shear stresses due to high sub-glacial water pressure and till rheology (e.g. Clark 1994; Hooyer and Iverson, 2002).

Following an initial advance at $\sim 20 \mathrm{ka}$, the Des Moines lobe re-advanced to reach its late-glacial maximum position at the Bemis Moraine in central lowa (Figure 1) at $\sim 14.0{ }^{14} \mathrm{C}$ ka BP ( 17.0 cal ka BP, calibration using Intcal13 Reimer et al., 2013 and presented as the median value) (Clayton and Moran, 
1982; Halberg and Kemmis, 1986). Subsequent re-advances to the Altamont and Algona moraines in northern lowa occurred by $\sim 13.5{ }^{14} \mathrm{C}$ ka BP ( 16.3 cal ka BP) and $\sim 12.6{ }^{14} \mathrm{C}$ ka BP ( 14.8 cal ka BP) respectively (Figure 1, Clayton and Moraine, 1982). Following formation of the Algona Moraine, the Des Moines lobe is suggested to have stagnated leaving dead ice covering most of its former extent in Minnesota (Clayton and Moraine, 1982). However, the presence of several minor moraines in central Minnesota (e.g. Leverett, 1932; Gwyne, 1951) indicates active ice-margin processes during retreat (Figure 1). Glacial Lake Benson formed during this phase of retreat as water ponded between the Echo and outer Big Stone moraines in the upper Minnesota River valley (Figure 1, Rittenour et al., 1998).

After retreat from the position of the outer Big Stone moraine, ice re-advanced to the inner Big Stone moraine and the glacial Pomme de Terre River formed along its eastern margin (Condit et al., 2010). This second phase is characterized by clay-rich diamict suggesting an ice marginal lake was overridden (Patterson et al. 1999). Geomorphic relationships indicate that glacial Lake Benson had drained by this time as delta deposits did not form where the glacial Pomme de Terre River enters the Lake Benson basin (Friedrich and Loughry, 2000). Age constraints from radiocarbon dating suggest advance to the inner Big Stone moraine occurred prior to $\sim 12.0{ }^{14} \mathrm{C}$ ka BP ( 14.0 cal ka BP) (Figure 1, Clayton and Moran, 1982; Lepper et al., 2007). Glacial Lake Agassiz later formed in the Red River valley as water ponded between the Big Stone Moraine and retreating ice margin.

\section{INSERT FIGURE 1 HERE}

Glacial Lake Agassiz is characterized by three lake-level phases. Briefly, these include the Lockhart Phase when the lake drained southward to the Gulf of Mexico via glacial River Warren, a pre-curser to the Minnesota River ( 14.1-13.5 cal ka, Herman, Norcross, Upham and Tintah strandlines), the Moorhead Phase when lake levels fell and the southern outlet was abandoned $\left(\sim 11.0{ }^{14} \mathrm{C}\right.$ ka BP, $12.8 \mathrm{cal}$ ka) and the Emerson Phase when lake levels rose and the southern outlet was re-occupied ( 10.5 cal ka, 
Campbell strandline) (Teller et al., 1983; Fisher et al., 2003; 2005; Lepper et al., 2007; 2013). Following the Emerson Phase the southern outlet was abandoned and the lake shifted northward as the ice margin migrated towards Hudson Bay. At 8.2 ka the then combined Lake Agassiz and Lake Ojibway rapidly drained to the Arctic Ocean producing a short-lived cooling event in the Northern Hemisphere

99 (e.g. Teller et al., 2002; Clarke et al., 2004).

No direct age control previously existed for the timing of glacial Lake Benson, however based on 101 geomorphic relationships, it must have formed following retreat of the Des Moines lobe from the Algona moraine by $\sim 12.6{ }^{14} \mathrm{C}$ ka BP ( 14.8 cal ka BP, Clayton and Moran, 1982) but prior to initial formation of glacial Lake Agassiz at $14.1 \pm 1.2 \mathrm{ka}$, based on mean OSL ages from the Herman strandline 104 (Lepper et al., 2013). Glacial River Warren, the southern outlet channel for Lake Agassiz, cuts through the glacial Lake Benson basin and geomorphic evidence suggests that Lake Benson was no longer present by the time of initial drainage of Lake Agassiz. Other evidence for the timing of Lake Benson

107 comes from lowest radiocarbon age collected a small kettle lake near the northwestern shore of Lake 108 Benson that suggest that ice had retreated from the Lake Benson basin by $13.7 \pm 0.2$ cal ka BP $(11,850 \pm$ $85{ }^{14} \mathrm{C}$ ka ETH-32335, Lepper et al., 2007).

\subsection{Glacial Lake Benson}

112 and generally flat topography below $1050 \mathrm{ft}$ asl $(320 \mathrm{~m}$ ) in the upper Minnesota River valley (Diedrick et 113 al., 1973, Diedrick and Rust, 1975). Subsequently glacial Lake Benson appeared on the Quaternary 114 Geologic map of Minnesota (Hobbs and Goebel, 1982) and has been further defined as part of mapping 115 efforts in the region (e.g., Patterson et al., 1999; Harris, 2006). 
couplets were identified and indicate that glacial Lake Benson was short-lived and the ice margin

119 retreated rapidly between the Echo and Big Stone moraines (69 km distance) without evidence for ice

120 re-advance. Rittenour et al. (1998) described shorelines features at $\sim 1070-1080 \mathrm{ft}$ asl ( 328 m) and

121 identified Chetamba Creek as the outlet spillway and the Echo moraine as the dam for the lake. Lake

122 levels at $335 \mathrm{~m}$ and $328 \mathrm{~m}$ were identified based on delta deposits in the northeastern portion of the

123 lake basin (Mauss and Reiss, 2000; Solmonson, 2001). The higher lake level is interpreted to reflect

124 short-lived local damming following initial ice pull back from the Alexandria moraine to the east (Wright

125 et al., 1973; Cotter, 1993). The presence of deltas at $328 \mathrm{~m}$ at the mouth of the East Branch Chippewa

126 River and the main Chippewa River to the north indicate that glacial Lake Benson maintained a stable

127 lake level throughout ice retreat within the basin.

128 3. Study sites

As part of this study, seven OSL samples were collected in order to improve the chronology of ice retreat and provide the first direct age constraints on the formation of glacial Lake Benson. Sample sites

131 were chosen to track the retreat of the ice margin and formation of Lake Benson. Ice-contact and ice132 marginal deposits can be very difficult to date with OSL methods due to limited transport distances and 133 potential for incomplete solar resetting of the luminescence signal (Fuchs and Owen, 2008; King et al., 134 2013). Therefore, care was taken to select the most suitable sediments for sampling based on 135 sedimentary structures and the degree of sorting, while still being cognizant of only sampling deposits 136 that can be linked to known ice margins. As a related goal, we examined equivalent dose distributions 137 to test the ability of single-grain OSL dating to provide age constraint for a variety of challenging 138 deposits and inform the most suitable deposits for OSL dating. Sample sites are described from south to 139 north, following the expected pattern of ice retreat (see Figure 1 and S1). 
The southernmost sample collected for this study was from a small kame-like hill in the

142 northeastern portion of the lake basin that contains at least 6-8 $\mathrm{m}$ of well-sorted, medium-grained

143 deltaic sands (Figure S1a). Sediments contain numerous closely spaced micro-faults displaying normal

144 and reverse displacement indicating shear. This deltaic deposit is capped in places by diamict and

145 isolated boulders. Given the inverted topography of this isolated hill, lack of geomorphic evidence for a

146 tributary stream, evidence for shear and the presence of capping boulders and diamict, this deposit is

147 interpreted to represent a supra-glacial lake deposit that was let-down during ice wasting.

148 Sample USU-1256 was collected from the upper portion of the deposit in faulted rippled sands 149 underlying a sandy diamict and a large granitic boulder (see Figure S1c). As this sample was collected 150 from the southern-most location, it is expected that it will record the earliest deposition related to ice 151 retreat in the region. However, given the supra-glacial nature of this deposit, it could have formed at 152 any time prior to deglaciation.

\subsection{Sites $B$ and C: pro-glacial delta}

The next two OSL samples were collected from pro-glacial delta deposits of the East Branch

155 Chippewa River where it enters into the glacial Lake Benson basin (Figure S1a). The higher delta is 156 positioned at $335 \mathrm{~m}$ asl (site $\mathrm{C}$ ) and is less extensive than the lower and geomorphically younger delta at

$157328 \mathrm{~m}$ asl (site B). Where sampled, the upper delta is composed predominantly of sandy deposits while 158 the lower delta is composed of pebble-gravel deposits with occasional sand lenses (Figure S1d,e).

Sample USU-1253 was collected from the upper delta at site C and sample USU-1255 was collected

160 from the lower-level delta at site B. These samples can be used to test the timing of the two lake-level 161 phases of glacial Lake Benson. It is expected that the higher lake level was established during early ice 162 retreat in the basin and that the lower, stable lake level was established after the ice margin migrated to 163 the position of the outer (recessional) Big Stone moraine. 


\subsection{Site D: ice-proximal deposit}

Site D is located upstream of sites B and C along the margin of the East Branch Chippewa River

166 valley. Deposits are characterized by cross-bedded sand and gravel and contain ice-collapse features

167 and diamict facies with evidence of post-depositional fluidized flow (Mauss and Reiss, 2000).

168 Sedimentary and geomorphic evidence suggests an ice-proximal setting for the deposits at this site.

Sample USU-1254 was collected from rippled sands overlying a package of diamict conformably

170 overlying a package of cross-bedded sand and gravel (Figure S1f). The juxtaposition of facies suggests a

171 dynamic ice-marginal location. The rippled sands at the site were chosen over the higher-energy cross-

172 bedded sand and gravel below the diamict to improve chances of solar resetting in this ice-proximal

173 setting. Given the setting of site D, sample USU-1254 is expected to provide an age for early fluvial

174 deposition following ice retreat in the northeastern portion of the lake basin.

1753.4 Site E: sub-glacial deposit

Site $E$ is located within a series of linear, discontinuous ridges composed of sand and gravel (Figure

177 S1a). These ridges, known as the Blue Mounds, have been interpreted to represent various depositional

178 environments such as eskers (Hobbs and Goeble, 1982), crevasse-fill deposits (Komai et al., 2000) and

179 inter-lobe features deposited between the Des Moines lobe in the Minnesota River valley and ice on the 180 Alexandria moraine (Reid, 1974).

Sample USU-1254 was collected from a sand bed within the predominantly gravel sequence at site E

182 (Figure S1g). While sediment sourced from an entirely sub-glacial setting is not expected to have been

183 optically reset prior to deposition, it is possible that the sediments could have been derived from supra-

184 glacial and ice-marginal streams. Populations of reset grains can help to test hypotheses about the 
origin of these ridges. However, it has also been suggested that shearing in sub-glacial settings may also

186 reset OSL signals (Bateman et al., 2012), possibly confounding interpretations.

\subsection{Site F: glacial fluvial deposit}

The next two OSL samples (USU-1250 and USU-1251) were collected from trough-crossbedded sands and gravel in a glacial-fluvial terrace along the Pomme de Terre River at site F (Figure S1a,h).

Given the lack of a delta at the mouth of the Pomme de Terre River it is expected that the OSL ages from

191 these samples will post-date the drainage of glacial Lake Benson. These samples may also constrain the 192 timing of ice re-advance to the inner Big Stone moraine position as the glacial Pomme de Terre River has been interpreted as an ice-marginal stream (Condit et al., 2010).

\section{Methods}

Samples for OSL dating were collected by pounding metal pipes into the sediment exposures and collection of the surrounding sediment for dose-rate analysis. Quartz sand was purified using

197 hydrochloric $(\mathrm{HCl})$ acid to remove carbonates, density separation $\left(2.7 \mathrm{~g} / \mathrm{cm}^{3}\right.$ sodium polytungstate) to 198 remove heavy minerals and $47 \%$ hydrofluoric acid to remove feldspars and etch the quartz, followed by $19937 \% \mathrm{HCl}$ to remove fluorites.

OSL samples were analyzed using the single-aliquot regenerative-dose (SAR) technique (Murray and

201 Wintle, 2000) on a Risø OSL/TL DA-20 luminescence reader with a single-grain attachment (Bøtter-

202 Jensen et al., 2000) using a green laser $(532 \mathrm{~nm})$ at $90 \%$ power $\left(135 \mathrm{~mW} / \mathrm{cm}^{2}\right)$ and detection through a

203 7.5-mm UV filter (U-340). Luminescence signals were measured over 1 second and calculated by

204 subtracting the average of the last $0.2 \mathrm{~s}$ from the initial $0.05 \mathrm{~s}$ of the luminescence signal. Preheat

205 temperatures following administered and natural doses were $240^{\circ} \mathrm{C}$ for 10 s and cutheat temperatures

206 following test doses ( $10 \mathrm{~Gy}$ ) were $160^{\circ} \mathrm{C}$ for $10 \mathrm{~s}$, as indicated by preheat plateau test results from small 207 aliquots and dose recovery tests on single-grain analyses (see Figures S2 and S3 and captions for details). 
Single-grain equivalent dose $\left(D_{E}\right)$ estimates were calculated using the minimum age model (MAM,

209 Galbraith et al., 1999) on at least 70 grains that passed rejection criteria. Grains were rejected if they

210 had evidence of feldspar contamination (IR depletion ratios >2), low luminescence signals (signal to

211 background ratios $<3$ for administered doses), poor recycling ratios ( $>30 \%$ difference in corrected

212 response between repeated doses), high recuperation (>20\% of the natural signal generated during the

213 zero-dose step), $D_{E}$ greater than the highest regenerative dose, and/or high error due to a poor dose-

214 response growth-curve fit (Table S1). MAM $D_{E}$ estimates were calculated using $15 \%$ over-dispersion (OD)

215 based on single-grain dose-recovery test results (11.5\% OD, see Figure S3 and caption) and assumptions

216 of additional OD due to microdosimetry effects on single-grain data.

217 Samples for water content and dose-rate determination were collected from a $30 \mathrm{~cm}$ diameter

218 area surrounding each OSL sample tube. Radioisotope concentrations were determined using ICP-

219 MS/ICP-AES analysis and uncertainty in elemental concentrations was calculated following Rittenour et

220 al. (2005). Elemental concentrations were converted to dose rate using the conversion factors of Guérin

221 et al. (2011) and beta attenuation coefficients of Brennan (2003) (Table S2). Total dose rates were

222 calculated based on water content, cosmic contribution (Prescott and Hutton, 1994) and radioisotope

223 concentration.

224 Single-grain OSL ages were calculated by dividing the $D_{E}$ value (in Grays, $1 \mathrm{~Gy}=1 \mathrm{~J} / \mathrm{kg}$ ) by the dose-

225 rate (Gy/ka). OSL ages are reported at 1-sigma standard error (Table 1) and include errors related to

226 instrument calibration and dose rate and equivalent dose calculations.

\section{5. Results}

OSL ages are presented in Table 1 and single-grain $D_{E}$ distributions are presented in Figure $S 4$. At

229 the onset of this project it was expected that OSL dating would be difficult in the ice-proximal settings targeted for dating the timing of ice retreat and formation of glacial Lake Benson. Precautions were 
231 taken in the field to sample ice-proximal deposits that were most likely to have been reset prior to

232 deposition and single-grain OSL dating was employed to allow the greatest resolution possible in

233 identifying reset populations of grains.

INSERT TABLE 1 HERE

Single-grain $D_{E}$ results showed considerable scatter and evidence for partial bleaching. As displayed

237 positive skew and over-dispersion values ranging from $\sim 40-60 \%$, both indicators of partial bleaching (e.g.

238 Olley et al., 1999). Moreover, luminescence signal intensities were weak and $\sim 90 \%$ of grains were

239 rejected due to lack of signal (Table S1). After rejection of grains that did not meet data quality checks,

240 acceptance rates were $\sim 4-6 \%$.

241 Single-grain OSL results show promise for dating ice-marginal deposits within glacial Lake Benson.

242 Samples from the East Branch Chippewa River valley (sites B-D) produced a series of tightly grouped

243 ages between 14.4-14.8 ka (Table 1). These samples were from upper and lower Lake Benson deltas and

244 ice-proximal deposits feeding these deltas. As expected the upper delta produced an older age (14.8 \pm

$2451.8 \mathrm{ka})$ than the lower delta $(14.4 \pm 1.8 \mathrm{ka})$, which was developed into the regionally stable lake level

246 (328 m asl). Rippled sands overlying diamict at site D produced an intermediate age of $14.6 \pm 1.9 \mathrm{ka}$

247 (Figure S1).

Samples collected from near the top and center a glacial stream terrace along the Pomme de Terre

249 River (site F) produced ages of $14.5 \pm 1.8 \mathrm{ka}$ from basal cross-bedded gravels and $13.7 \pm 1.8 \mathrm{ka}$ from

250 upper capping sands (Table 1). These results fit well with expected geomorphic relationships. Based on

251 the lack of a delta deposit at the mouth of the Pomme de Terre River it was expected that this terrace

252 would be younger than the delta deposits at the mouth of the East Branch Chippewa River valley (14.4-

$253 \quad 14.8 \mathrm{ka})$. 
The samples described above from the East Branch Chippewa and Pomme de Terre River valleys

date to 13.7-14.8 ka and provide age control for deglaciation of the Lake Benson basin that is consistent with the regional ice-retreat chronology. In contrast, samples collected from supra-glacial and sub-

257 glacial settings produced older age results. These are discussed in greater detail below.

Sample USU-1256 was collected from a deposit interpreted to be a supra-glacial lake deposit that was let-down onto the landscape during ice decay. Given the interpreted supra-glacial setting, it was expected that it would be well bleached and ideal for OSL dating. However, OSL results reveal similar skew and over-dispersion as with the other samples (Figure 2, Table 1). The resultant age of $15.7 \pm 2.0$

$262 \mathrm{ka}$ is older than expected for the timing of deglaciation in the region. However, this result may reflect supra-glacial lake formation during initial stagnation and retreat of the Des Moines lobe from the Algona moraine (prior to $14.8 \mathrm{ka}$, Halberg and Kemmis, 1986).

267 may reflect esker, crevasse-fill or an inter-lobe setting. The positive relief of the Blue Mounds ridges 268 suggests an ice-contact or sub-glacial setting. $D_{E}$ distributions from sample USU-1252 show high over269 dispersion and skew (Table 1), suggesting partial bleaching. This sample has a much greater range in $D_{E}$ 270 values than other samples. For example, $D_{E}$ values ranged from $20-260 \mathrm{~Gy}$ (Figure S4) and 8\% of 271 grains were rejected due to $D_{E}$ values $>300$ Gy that were not bracketed by the dose-response curve 272 during measurement ( $\mathrm{n}=145$ grains, Table S1). Use of the MAM produced a good fit with a population 273 of lower $D_{E}$ grains and an apparent age of $18.7 \pm 2.1 \mathrm{ka}$. Given that we cannot be certain if the 274 sediments were exposed to light prior to deposition, we are hesitant to interpret this age result as the 275 timing of the formation of the Blue Mounds. Instead it is possible that this apparent age reflects sub276 glacial transport of older deposits without solar resetting or a period of resetting due to glacial shear 
277 (e.g. Bateman et al., 2012). The apparent age of $18.7 \mathrm{ka}$ is intriguing as it may reflect sub-glacial re-

278 deposition of sediments associated with ice-free conditions in the region following an advance at $\sim 20 \mathrm{ka}$

279 but prior to re-advance to the position of the Bemis moraine at 17 ka (Halberg and Kemmis, 1986).

\section{Discussion}

Samples for OSL dating were collected from five ice-proximal settings in order to test the suitability of single-grain OSL dating in glacial settings and to provide age constraint for the timing of ice retreat and formation of glacial Lake Benson in west-central Minnesota.

\subsection{Relationship between $D_{E}$ distribution and depositional setting}

As part of the first goal of this project, the level of solar resetting in each depositional environment

was assessed by analyzing single-grain $D_{E}$ distribution characteristics. As described above, $D_{E}$ distributions from all samples show signs of incomplete solar resetting as evidenced by high overdispersion and significant positive skew. Figure 2 plots these metrics along with the percent of grains within $2 \sigma$ error of the MAM $D_{E}$ value. Results suggest that processes in glacial- and fluvial-dominated environments produce different ranges for skew and over-dispersion in single-grain $D_{E}$ distributions.

\section{INSERT FIGURE 2 HERE}

In summary, depositional environments identified in the field as dominated by glacial processes, such as sub-glacial (site E, USU-1252) and supra-glacial settings (site A, USU-1256), were found to have over-dispersion values greater than $50 \%$ and values of skew greater than 0.9 (Figure 2, Table 1).

295 Moreover, less than $25 \%$ of the accepted grains were within error of the MAM $D_{E}$ values for these 296 samples (Figure 2, S4). In contrast, deposits identified in the field as dominated by fluvial processes, 297 such as deltaic deposits at the mouth of the East Branch Chippewa River (site C and B, USU-1253 and 298 USU-1254) and the glacial fluvial deposits in Pomme de Terre River valley (site F, USU-1250 and USU- 
1251), have $D_{E}$ over-dispersion values less than $50 \%$, values of skew generally less than 0.9 and greater than $25 \%$ of the grains lie within 2-sigma error of the MAM $D_{E}$ value (Figure 2, Table 1). These observations from $D_{E}$ distributions probably reflect the greater bleaching potential within glacial-fluvial systems in comparison to glacial-dominated environments. This is likely due to longer sediment transport distances in the fluvial settings, although all samples were collected from ice-proximal settings (less than $5 \mathrm{~km}$ from the ice margin).

Sample USU-1254 was collected from ice-proximal deposits associated with re-deposited diamict and ice-collapse features. The interpreted depositional environment for this sample is neither fully 307 glacial nor fully fluvial as evidence for both processes are seen at site D. Moreover, the skew of this 308 sample lies outside values for either end-member category (Figure 2). While $D_{E}$ over-dispersion was $49.3 \%$, or just below the $50 \%$ base-line derived from glacial-process dominated deposits, the skew was the highest value of all samples analyzed (1.49) and this sample has the second highest percent of grains

311 within error of the MAM $D_{E}$ (Figure 2, Table 1). Interestingly, although this sample suffers from high 312 over-dispersion and skew, the calculated OSL age (14.6 ka) is in line with the regional chronology of ice 313 retreat and consistent with OSL ages from fluvial-dominated delta settings that display greater evidence

314 for solar resetting prior to deposition (Table 1). While these metrics are commonly interpreted to 315 represent evidence for partial bleaching, it has been suggested that high over-dispersion and large skew 316 may instead be an indicator of a higher degree of bleaching in single-grain populations (King et al., 317 2013). Conclusions from analysis of samples from this study suggest that samples collected from settings 319 dominated by glacial processes (sub-glacial and supra-glacial deposits) were characterized by high over320 dispersion (> 50\%), large positive skew in $D_{E}$ distributions $(>0.9)$ and smaller percentages of grains within 321 error of the MAM $D_{E}$ value (<25\%) than samples collected from fluvial-dominated settings (Figure 2 ). 
322 Implications of these results are that deposits transported by fluvial processes, in contrast to glacial

323 processes, should be targeted for sampling ice-proximal environments. This is not meant to suggest that

324 only deposits entirely fluvial in nature should be sampled. Instead water-transported pro-glacial

325 deposits should be targeted when multiple facies are present within a deposit. Sample USU-1254 at site

$326 \mathrm{D}$ is a good example. While deposits at this site indicate an ice-proximal to ice-contact setting, results

327 from this sample are consistent with delta deposits downstream in the same valley. While OSL ages

328 obtained from deposits originating from glacial-dominated processes may be producing accurate ages

329 for the last resetting event, more work is needed to better test the application of OSL dating to sub-

330 glacial and supra-glacial deposits from this continental glacial setting.

\subsection{Revised chronology of ice retreat and formation of glacial Lake Benson}

The second goal of this pilot project was to provide age control for the timing of ice retreat and formation of glacial Lake Benson in the upper Minnesota River valley. Samples were collected from deposits that can be linked to ice-margin positions for this purpose. As described above, samples from

335 fluvial-dominated settings provided the best results regarding $D_{E}$ distributions and are the focus of the 336 discussion.

Single-grain OSL results from the upper delta deposit at the mouth of the East Branch Chippewa

338 River valley constrain deglaciation of the northeastern portion of the lake basin and initial formation of 339 Lake Benson to prior to $14.8 \pm 1.8 \mathrm{ka}$ (USU-1253, Table 1). Ice-proximal sands in the delta graded to the 340 stable lower elevation of glacial Lake Benson suggest the lake persisted until $14.4 \pm 1.8$ ka (USU-1255, 341 Table 1). OSL results from the Pomme de Terre River valley produced ages that are generally younger 342 than the results from the East Branch Chippewa River valley (14.5 \pm 1.8 ka and $13.7 \pm 1.8$ ka Table 1$)$. 343 These ages are expected to bracket drainage of glacial Lake Benson and ice re-advance to the inner Big 344 Stone Moraine. The single-grain OSL ages presented here are consistent with previous radiocarbon age 
constraints limiting deglaciation to 15-14 cal ka BP (Clayton and Moran, 1982) and OSL ages from Lake

346 Agassiz shorelines that limit the formation of glacial Lake Benson to prior to $14.1 \mathrm{ka}$ (Lepper et al., 2013).

347 Moreover, the narrow and overlapping age constraints for the timing of glacial Lake Benson are

348 consistent with geomorphic and sedimentary evidence that suggests rapid ice retreat in the region and

349 short duration of the lake (e.g. Rittenour et al., 1998).

\section{Conclusions}

351

Single-grain OSL results from ice-proximal and deltaic settings provide the first direct age control for

352 the timing of ice retreat and formation of glacial Lake Benson in the upper Minnesota River valley.

353 Analysis of metrics related to $D_{E}$ distributions indicate that while all samples displayed evidence for

354 partial bleaching, settings dominated by glacial processes have higher over-dispersion (> 50\%) and

355 greater positive skew $(>0.9)$ in single-grain $D_{E}$ distributions than samples from fluvial-dominated

356 settings. Results suggest deglaciation of the northeastern portion of the lake basin by $14.8 \mathrm{ka}$ and

357 development of the stable lake level by 14.4 ka. Future work will target samples that can be linked to

358 additional ice-margin and lake-level positions to help improve the resolution of the largely radiocarbon-

359 based chronology of ice retreat in the region. Sample selection will be guided by results suggesting that

360 ice-proximal deposits dominated by fluvial processes are better suited for OSL dating than deposits

361 originating from glacial-dominated processes.

362

363 Acknowledgments

This research was supported by grants from the National Science Foundation REU Program awarded

to J.F.P. Cotter (NSF EAR 0353621, NSF EAR 0640575 and NSF EAR 9100630) and the Utah State

367 manuscript. 
Balco, G., Stone, J. O., Porter, S. C., Caffee, M. W., 2002. Cosmogenic-nuclide ages for New England coastal moraines, Martha's Vineyard and Cape Cod, Massachusetts, USA. Quaternary Science Reviews 21, 2127-2135.

Bateman, M. D., Swift, D. A., Piotrowski, J. A., Sanderson, D. C., 2012. Investigating the effects of glacial shearing of sediment on luminescence. Quaternary Geochronology 10, 230-236.

Black, R.F., 1976. Quaternary geology of Wisconsin and contiguous Upper Michigan. in Mahaney, W.C. (ed.) Quaternary Stratigraphy of North America. Dowden, Hutchinson and Ross, Stroudesburg, Pennsylvania, 93-117.

Bøtter-Jensen, L., Bulur, E., Duller, G.A.T., Murray, A.S., 2000. Advances in luminescence instrument systems. Radiation Measurements 32, 523-528.

Brennan, B. J., 2003. Beta doses to spherical grains. Radiation Measurements 37, 299-303.

Clark, P. U., 1994. Unstable behavior of the Laurentide Ice Sheet over deforming sediment and its implications for climate change. Quaternary Research 41, 19-25.

Clark, P.U., Marshall, S.J., Clarke, G.K.C., Hostetler, S.W., Licciardi, J.M., Teller, J.T., 2001. Freshwater forcing of abrupt climate change during the last glaciation. Science 293, 283-287.

Clarke, G. K., Leverington, D. W., Teller, J. T., Dyke, A. S., 2004. Paleohydraulics of the last outburst flood from glacial Lake Agassiz and the 8200BP cold event. Quaternary Science Reviews 23, 389-407.

Clayton, L., Moran, S. R., 1982. Chronology of late Wisconsinan glaciation in middle North America. Quaternary Science Reviews 1, 55-82.

Condit, C., Eveleth, R. and Cotter, J.F.P., 2010. The multi-stage formation of the Big Stone Moraine, West-Central Minnesota: Geomorphologic Analysis of the ice-marginal, glacial Chippewa River. Geological Society of America meeting (Northeastern section) Abstracts with programs v. 42, no. 2.

Cotter, J. F. P., Evenson, E. B., Sirkin, L. A., Stuckenrath, R., 1984. The interpretation of "bog-bottom" radiocarbon dates in glacial chronologies. Correlation of Quaternary Chronologies, Geo Books, Norwich, England, 299-316.

Cotter, J.F.P., 1993, The Alexandria Moraine Complex: a "complex moraine": Guidebook to the Geological Society of Minnesota, Field Trip \#1, 32 pp.

Diedrick, R.T., Harries, J.C., Larsen, P.L., Miller, E.L., Rhyner, A.G., Murray, J.J., Sutton, C.K., 1973. Soil Survey of Swift County Minnesota, US Department of Agriculture, Soil Conservations Service, 116 p.

Diedrick, R.T., Rust, R.H., 1975. Glacial lake evidence in western Minnesota as interpreted from soil survey. Minnesota Academy of Science Journal 41, 9-12. 
Duller, G.A.T., 2003. Distinguishing quartz and feldspar in single grain luminescence measurements. Radiation Measurements 37, 161-165.

Duller, G.A.T., 2008. Single-grain optical dating of Quaternary sediments: why aliquot size matters in luminescence dating. Boreas 37, 589-612.

Duller, G. A. T., Bøtter-Jensen, L., Kohsiek, P. Murray, A. S., 1999. A high-sensitivity optically stimulated luminescence scanning system for measurement of single sand-sized grains. Radiation Protection Dosimetry 84, 325-330.

Dyke, A. S., Prest, V. K., 1987. Late Wisconsinan and Holocene history of the Laurentide ice sheet. Géographie physique et Quaternaire 41, 237-263.

Fisher, T.G., 2003. Chronology of glacial Lake Agassiz meltwater routed to the Gulf of Mexico. Quaternary Research 59, 271-276.

Fisher, T.G., 2005. Strandline analysis in the southern basin of glacial Lake Agassiz, Minnesota and North and South Dakota, USA. Geological Society of America Bulletin 117, 1481-1496.

Friedrich, H. G. and Loughry, J. E., 2000, The history of Glacial River Pomme de Terre; Ottertail, Grant, Stevens and Swift Counties, Minnesota. Geological Society of America (North central section) Abstracts with programs, V. 32, no. 4

Fuchs, M., Owen, L. A., 2008. Luminescence dating of glacial and associated sediments: review, recommendations and future directions. Boreas 37, 636-659.

Galbraith, R.F., Roberts, R.G., Laslett, G.M., Yoshida, H., Olley, J.M., 1999. Optical dating of single and multiple grains of quartz from Jinmium rock shelter, northern Australia: Part I. Archaeometry 41, 339-364.

Guérin, G., Mercier, N., Adamiec, G., 2011. Dose-rate conversion factors: update. Ancient TL 29, 5-8.

Gwynne, C. S., 1951. Minor moraines in South Dakota and Minnesota. Geological Society of America Bulletin 62, 233-250.

Hallberg, G. R., Kemmis, T. J., 1986. Stratigraphy and correlation of the glacial deposits of the Des Moines and James lobes and adjacent areas in North Dakota, South Dakota, Minnesota, and lowa. Quaternary Science Reviews 5, 65-68.

Harris, K.L., 2006. Regional hydrogeologic assessment: Quaternary geology-Traverse-Grant County Area, West-Central Minnesota. Minnesota Geological Survey Regional Hydrogeologic Assessment RHA-6, scale 1:200,000.

Hobbs, H.C., Goebel, J.E., 1982. Geologic map of Minnesota, Quaternary geology.Minnesota Geological Survey State Map S-1, 1 pl., scale 1:500,000. 
Hooyer, T. S., Iverson, N. R., 2002. Flow mechanism of the Des Moines lobe of the Laurentide ice sheet. Journal of Glaciology 48, 575-586.

Hughen, K. A., Southon, J. R., Lehman, S. J., Overpeck, J. T., 2000. Synchronous radiocarbon and climate shifts during the last deglaciation. Science 290, 1951-1954.

Huntley, D.J., Godfrey-Smith, D.I., Thewalt, M.L.W., 1985. Optical dating of sediments. Nature 313, 105107.

Jennings, C. E., 2006. Terrestrial ice streams-a view from the lobe. Geomorphology 75, 100-124.

King, G. E., Robinson, R. A. J., Finch, A. A., 2013. Apparent OSL ages of modern deposits from Fåbergstø|sdalen, Norway: implications for sampling glacial sediments. Journal of Quaternary Science 28, 673-682.

Komai, L., Lien, J., Ferber, L., Cotter, J.F.P., 2000. Insights about the origin of the Blue Mounds in Pope County, Minnesota. Association for Women in Science 29, n. 3, 21-25.

Lepper, K., Fisher, T. G., Hajdas, I., Lowell, T. V., 2007. Ages for the Big Stone Moraine and the oldest beaches of glacial Lake Agassiz: Implications for deglaciation chronology. Geology 35, 667-670.

Lepper, K., Buell, A. W., Fisher, T. G., Lowell, T. V., 2013. A chronology for glacial Lake Agassiz shorelines along Upham's namesake transect. Quaternary Research 80, 88-98.

Leverett, F., 1932. Quaternary geology of Minnesota and parts of adjacent states. U.S. Geological Survey Professional Paper 161, 149 pp.

Mauss, S., Reiss, C., 2000. The Geology and Implications of the Swift falls delta Complex, Swift County, Minnesota. Geological Society of America (North central section) Abstracts with programs, v. 32, n. 4 p.5.

Murray, A.S., Wintle, A.G., 2000. Luminescence dating of quartz using an improved single-aliquot regenerative-dose protocol. Radiation Measurements 32, 57-73.

Olley, J. M., Caitcheon, G. G., Roberts, R. G., 1999. The origin of dose distributions in fluvial sediments, and the prospect of dating single grains from fluvial deposits using optically stimulated luminescence. Radiation Measurements 30, 207-217.

Overpeck, J. T., Otto-Bliesner, B. L., Miller, G. H., Muhs, D. R., Alley, R. B., Kiehl, J. T., 2006. Paleoclimatic evidence for future ice-sheet instability and rapid sea-level rise. Science 311, 1747-1750.

Patterson, C. J., 1997. Southern Laurentide ice lobes were created by ice streams: Des Moines Lobe in Minnesota, USA. Sedimentary Geology 111, 249-261.

Patterson, C. J., 1998. Laurentide glacial landscapes: The role of ice streams. Geology 26, 643-646. 
Patterson, C.J., 1999. Regional hydrogeologic assessment: Quaternary geology-upper Minnesota River basin, Minnesota. Minnesota Geological Survey Regional Hydrogeologic Assessment RHA-4, part A, 2 plates, scale 1:200,000.

Prescott, J.R., Hutton, J.T., 1994. Cosmic ray contributions to dose rates for luminescence and ESR dating. Radiation Measurements 23, 497-500.

Reid, D.F., 1974. Quaternary Geology of the Lake Johanna region, west-central Minnesota. Unpubliahed M.S. Thesis, University of Minnesota Duluth, 91pp.

Reimer, P.J., Bard, E., Bayliss, A., Beck, J.W., Blackwel,I P.G., Bronk Ramsey, C., Buck, C.E., Cheng, H., Edwards, R.L., Friedrich, M., Grootes, P.M., Guilderson, T.P., Haflidason, H., Hajdas, I., Hatté, C., Heaton, T.J., Hoffmann, D.L., Hogg, A.G., Hughen, K.A., Kaiser, K.F., Kromer, B., Manning, S.W., Niu, M., Reimer, R.W., Richards, D.A., Scott, E.M., Southon, J.R., Staff, R.A., Turney, C.S.M., van der Plicht, J., 2013. IntCal13 and Marine13 radiocarbon age calibration curves 0-50,000 years cal BP. Radiocarbon 55, 1869-1887.

Rhodes, E. J., 2011. Optically stimulated luminescence dating of sediments over the past 200,000 years. Annual Review of Earth and Planetary Sciences 39, 461-488.

Ridge, J. C., Balco, G., Bayless, R. L., Beck, C. C., Carter, L. B., Dean, J. L., Voytek, E.B., Wei, J. H., 2012. The new North American Varve Chronology: A precise record of southeastern Laurentide Ice Sheet deglaciation and climate, 18.2-12.5 kyr BP, and correlations with Greenland ice core records. American Journal of Science 312, 685-722.

Rittenour, T.M., Geiger, K.L., Cotter, J.F.P., 1998. Glacial Lake Benson, west-central Minnesota. In: C.J. Patterson and H.E. Wright Jr. eds., Contributions to Quaternary Studies in Minnesota, Minnesota Geological Survey Reports of Investigations n. 49, p. 97-102.

Rittenour, T. M., Goble, R.J., Blum, M.D., 2005. Development of an OSL chronology for Late Pleistocene channel belts in the lower Mississippi valley, USA. Quaternary Science Reviews 24, 2539-2554.

Rittenour, T. M., 2008. Luminescence dating of fluvial deposits: applications to geomorphic, palaeoseismic and archaeological research. Boreas 37, 613-635.

Solmonson, L., 2001. Terraces of the East Branch Chippewa River, Pope and Swift Counties, Minnesota: a proglacial tributary to Glacial Lake Benson. Geological Society of America, Abstracts with programs, v. 33 , no. 2 .

Steffensen, J. P., Andersen, K. K., Bigler, M., Clausen, H. B., Dahl-Jensen, D., Fischer, H., Goto-Azuma, K., Hansson, M., Johnsen, S.J., Jouzel, J., Masson-Delmotte, V., Popp, T., Rasmussen, S.O., Röthlisberger, R., Ruth, U., Stauffer, B., Siggaard-Anderson, M.-L., Sveinbjörnsdóttir, A.E., Svensson, A., White, J. W., 2008. High-resolution Greenland ice core data show abrupt climate change happens in few years. Science 321, 680-684. 
497 Teller, J. T., Thorleifson, L. H., Dredge, L. A., Hobbs, H. C., Schreiner, B.T., 1983. Maximum extent and 498 major features of Lake Agassiz. In J. T. Teller and L. Clayton (eds.), Glacial Lake Agassiz. Geological $499 \quad$ Association of Canada Special Paper 26.

500 Teller, J. T., Leverington, D. W., Mann, J. D., 2002. Freshwater outbursts to the oceans from glacial Lake 501 Agassiz and their role in climate change during the last deglaciation. Quaternary Science Reviews 21, $502 \quad 879-887$.

503 Wright, H. E., Matsch, C. L., Cushing, E. J., 1973. Superior and Des Moines Lobes. Geological Society of $504 \quad$ America Memoirs 136, 153-185.

505 Wyshnytzky, C. E., Rittenour, T. M., Nelson, M. S., Thackray, G., 2015-in press. Luminescence dating of 506 late Pleistocene proximal glacial sediments in the Olympic Mountains, Washington. Quaternary 507 International, in press. DOI: 10.1016/j.quaint.2014.08.024

508 


\section{Table and Figure Captions}

510 Table 1. OSL age Information.

511 Figure 1. Location of glacial Lake Benson in west-central Minnesota and samples collected for OSL

512 dating. Also shown are general age constrains for ice marginal positions following Clayton and

$513 \quad$ Moran (1982) and other features and age constraints discussed in the text.

514 Figure 2. Equivalent dose-distribution metrics plotted versus sample number and depositional

515 environment. Note that samples from glacial-dominated depositional settings have higher overdispersion, greater skew, lower percentages of grains within error of the minimum age model (MAM) calculated equivalent dose and older age estimates than expected for the timing of deglaciation of the region than fluvial-dominated environments. All samples have significant skew. 
Table 1. OSL Age Information

\begin{tabular}{llllccccc}
\hline $\begin{array}{l}\text { Site } \\
\text { (Fig.1) }\end{array}$ & $\begin{array}{l}\text { USU lab } \\
\text { number }\end{array}$ & Deposit setting & OD $^{\mathrm{a}}(\%)$ & Skew $^{\mathrm{b}}$ & $\begin{array}{c}\text { Number of } \\
\text { grains }^{\mathrm{c}}\end{array}$ & $\begin{array}{c}\text { Dose rate } \\
\text { (Gy/ka) }\end{array}$ & $\begin{array}{c}\text { Equivalent dose }^{\mathrm{e}} \\
\pm 2 \sigma(\mathrm{Gy})\end{array}$ & $\begin{array}{c}\text { OSL age }^{\mathrm{f}} \\
\pm 1 \sigma(\mathrm{ka})\end{array}$ \\
\hline \hline A & USU-1256 & supra-glacial & 50.1 & $0.95^{*}$ & $83(2400)$ & $1.46 \pm 0.08$ & $22.85 \pm 3.19$ & $15.68 \pm 2.00$ \\
B & USU-1255 & delta (lower) & 41.7 & $0.53^{*}$ & $83(2200)$ & $1.50 \pm 0.08$ & $21.57 \pm 2.69$ & $14.40 \pm 1.83$ \\
C & USU-1253 & delta (upper) & 47.9 & $0.79^{*}$ & $93(1900)$ & $1.61 \pm 0.08$ & $23.92 \pm 3.11$ & $14.83 \pm 1.78$ \\
D & USU-1254 & ice-proximal & 49.3 & $1.49^{*}$ & $81(2200)$ & $1.50 \pm 0.08$ & $21.96 \pm 3.22$ & $14.61 \pm 1.85$ \\
E & USU-1252 & sub-glacial & 57.1 & $0.92^{*}$ & $105(1900)$ & $1.63 \pm 0.09$ & $30.38 \pm 3.87$ & $18.67 \pm 2.05$ \\
F & USU-1251 & glacial fluvial & 37.5 & $0.45^{*}$ & $72(2000)$ & $1.57 \pm 0.08$ & $21.63 \pm 3.05$ & $13.74 \pm 1.75$ \\
F & USU-1250 & glacial fluvial & 47.8 & $0.94^{*}$ & $98(1900)$ & $1.60 \pm 0.08$ & $23.11 \pm 3.02$ & $14.45 \pm 1.78$ \\
\hline
\end{tabular}

a Overdispersion (OD) is calculated as part of central age model Galbraith et al. (1999) and represents scatter in Equivalent dose $\left(D_{E}\right)$ beyond calculated uncertainties in data.

${ }^{b}$ Significant skew indicated with asterisk $\left(^{*}\right)$ as defined by a calculated value $>1$ when skew is divided by the square root of $6 / n$ where $n=$ number of accepted grains.

${ }^{\mathrm{c}}$ Number of grains used in age calculation and total number of grains analyzed in parentheses.

d See Table S2 for information on dose-rate calculation.

${ }^{e}$ Equivalent doses $\left(D_{E}\right)$ and ages calculated using the minimum age model of Galbraith et al. (1999) using excel macros written by S. Huot (UQAM) and $15 \%$ OD as determined by dose-recovery tests.

${ }^{f}$ Datum for OSL ages is 2010 AD. 

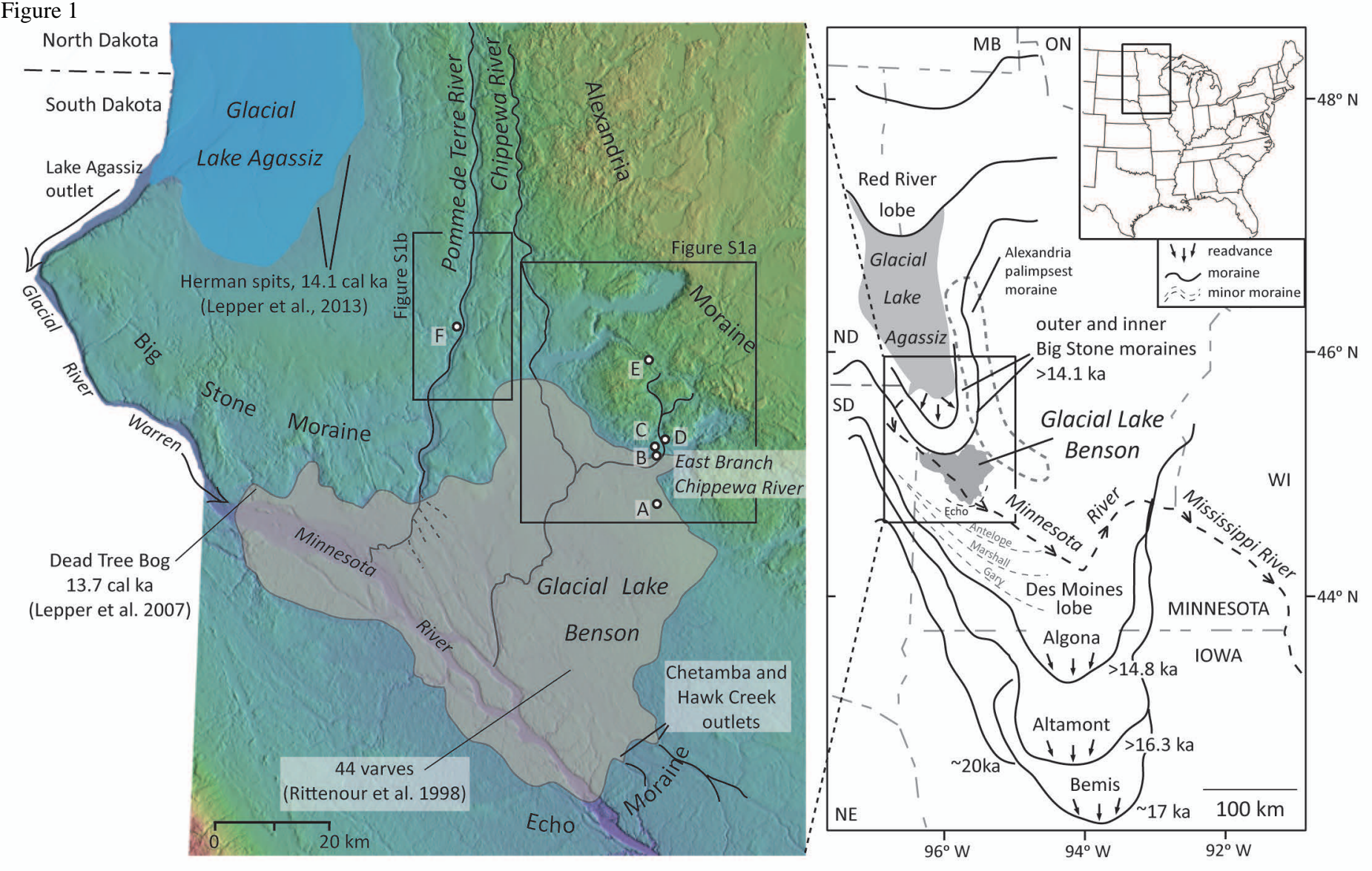


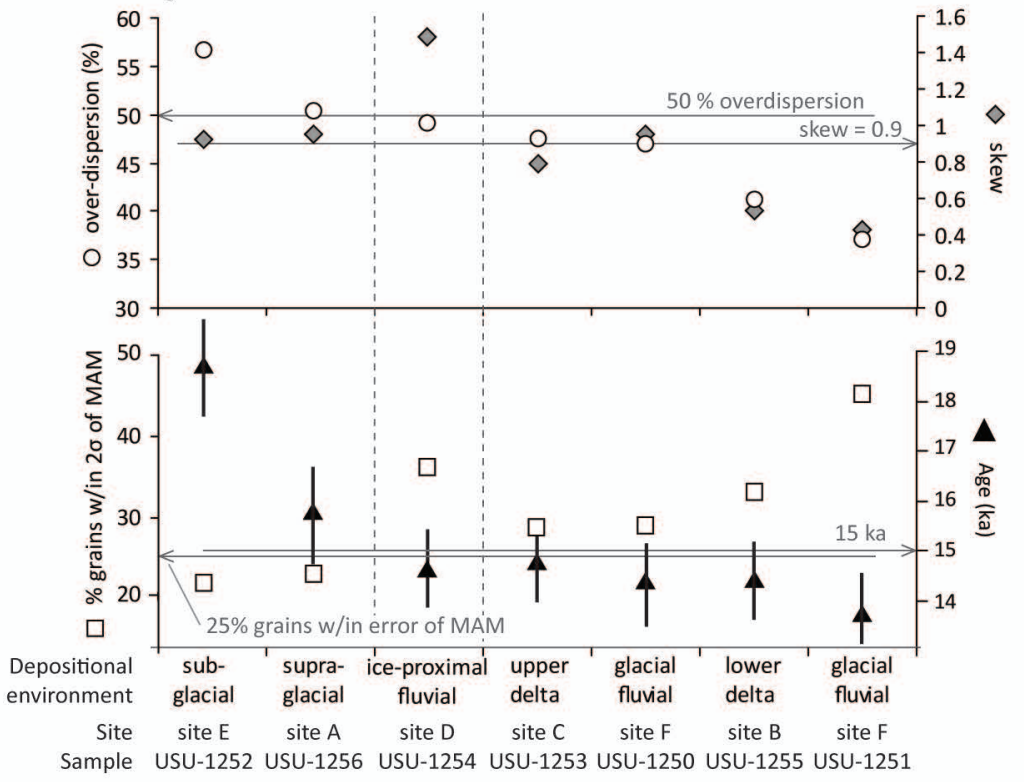

